Egypt. J. of Appl. Sci., 35 (5) 2020

\title{
SUPPLEMENTATION HOT PEPPER FOR IMPROVING UTILIZATION OF CORN GLUTEN MEAL IN BROILER CHICKS DIETS.
}

\author{
Azouz, H.M.M.
}

Anim. Prod. Res. Ins., Agric. Res. Center, Giza, Egypt.

Key Word: broiler, hot pepper, corn gluten meal, growth performance, carcass, villus and crypts.

\begin{abstract}
This experiment was conducted to investigate the effects of hot pepper and corn gluten meal (CGM) on growth performance, carcass traits, intestinal villi histo-morphometry and in broiler chicks reared for 42 days were evaluated. A total number of 180 unsexed one day-old Ross 308 broiler chicks were weighed individually, randomly allocated to six dietary treatments of three replicates each. Chicks were fed ad libitum during starter, grower and finisher stage. The experimental design consists of the following groups; the first group and the second were fed the basal diet containing 5\% or 10\% corn gluten meal without hot pepper and both served as controls, respectively. The third and fourth groups were fed the control diet (5\% CGM) supplemented with 0.1 or with 0.2 $\%$ hot pepper, respectively. The fifth and sixth groups were fed on the control diet(10\% CGM) supplemented with 0.1 or with $0.2 \%$ hot pepper, respectively. The results obtained could be summarized as follows: at 6 weeks of age, among the levels of dietary corn gluten meal, control diet with $(5 \%$ CGM) improved significantly $(\mathrm{P}<0.05)$ live body weight , body weight gain, feed conversion, dressing $\%$, and abdominal fat \% compared to the control with (10\% CGM) with no significantly differences for feed intake, liver \%, gizzard \%, and heart \%. Chicks fed diets containing hot pepper $(0.1 \%$ with $5 \% \mathrm{CGM})$, hot pepper $(0.2 \%$ with $5 \% \mathrm{CGM})$ and hot pepper $(0.2 \%$ with $10 \% \mathrm{CGM})$ recorded the heaviest $(\mathrm{P}<0.01)$ body weight and body wight gain than hot pepper $(0.1 \%$ and $10 \%$ CGM) and control (10\% CGM), with no significant differences between each other. The feed intake value, feed conversion, dressing $\%$ , abdominal fat $\%$ for hot pepper diets were significantly $(\mathrm{P}<0.01)$ less than those of control diets (10\% CGM).No significant differences were observed in liver $\%$, gizzard \%, and heart \% between broiler chicks fed hot pepper diets and control diets. There were significant increments in intestinal villi length associate with significant reduction in crypt depth due to feeding hot pepper compared with two levels of corn gluten meal. It could be concluded that, adding hot pepper into diets containing high level of corn gluten meal $(10 \%)$ improves broiler performance by improving intestinal health, resulting from increased villi length, and increasing absorptive surface of the small intestine.
\end{abstract}




\section{INTRODUCTION}

Corn plays a significant role in poultry diets. Corn gluten meal (CGM), a by-product of the corn wet-milling process employed for the production of corn starch, contains $600-710 \mathrm{~g} / \mathrm{kg}$ protein. The major protein fractions of the CGM are zein and glutelin, representing 680 and $280 \mathrm{~g} / \mathrm{kg}$ of total protein weight, respectively (Jin et al., 2015). Unfortunately, a large number of proteins in the CGM cannot be absorbed because of their compositions and structure (Bai et al., 2019). Gut morphology is one of the markers for gut health and can be assessed by villus length and crypt depth (Awad et al., 2009). There is a scarcity of published data regarding the effect of CP sources and their digestible levels on villus height and crypt depth in broilers. The shorter villus height and greater crypt depth in broilers fed rapeseed meal or corn gluten meal diets may be an indication of more damage to the gut by harmful compounds produced by microbial fermentation. These shorter villi indicate reduced intestinal health (Qaisrani et al., 2020). A shorter villus height may decrease the surface area for absorption of nutrients from the gut as villi are the functional units of nutrient absorption (Zang et al., 2009). As well corn gluten meal exerted negative effects on the intestinal health in turbot, including the induction of enteritis and impaired intestinal immune and antioxidative systems (Bai $\boldsymbol{e t}$ al., 2019). This represents a great loss of protein resources which could be used to resolve the problem of protein shortage caused by increasing population growth. Sufficient attention should be paid not only to the availability of food and its nutritional composition but also to the bioavailability of the nutrients during digestion (He et al, 2018). Capsaicin is one of the most important capsaicinoids and forms the main pungent ingredient of chili peppers. It is known to release biologically active substances which affect motility of gut in different species. In human, capsaicin has been shown to alter gastric emptying time . Capsaicin, acts through capsaicin receptor, Transient receptor potential subtype 1 (TRPV1). Capsaicin receptor immune reactivity has been also reported in different parts of the gut in different mammalian species (Singh and Mandal, 2015). Jamroz et al. (2006) reported that capsaicin significantly increased intestinal mucus production. Furthermore, capsaicin shows the ability to protect the microvilli because it reduces the adhesion of Escherichia coli and Clostridium perfringens. These functions of capsaicin may improve the conditions of the intestinal lumen, resulting in more hypertrophied epithelial cells. The increased light microscopic parameters and protuberant cells shown suggest that the function of villi and epithelial cells may be stimulated after feeding dietary red pepper $(0.05 \%)$. Moreover, the current histological hypertrophied villi and epithelial cells in the dietary red pepper suggest that intestinal absorptive function may be activated after feeding on red pepper, which was resulting improved egg yolk color in laying hens ( 
Lokaewmanee et al., 2012). The present work directly suggests that strategies to maintain intestinal health should be developed and undertaken when formulating broiler diets containing corn gluten meal by focused to improve its bioavailability by using hot pepper.

\section{MATERIALS AND METHODS}

The present study was carried out at the poultry experimental station of Al-Shaer Island Farm, Qanatr, Production Sector, Ministry Of Agriculture, from 1 Maye to 11 June. One hundred and eighty, one-day old unsexed Ross 308 broiler chicks were wing- banded, weighted individually and sorted into similar body weights. Chicks were allocated to six experimental groups; each group consists of three replicates (10 chicks/ replicate). All experimental chicks were brooded and raised in three tiers, wire floor battery cages in a closed broiler house, under the same managerial and hygienic conditions. The initial interior temperature was about $30^{\circ} \mathrm{C}$ during the first week. The temperature values $\left(36 \mathrm{C}^{\circ}\right)$ and the relative humidity percentages $(65-75 \%)$ were daily recorded by using a thermohygrograph. The artificial light was provided for completing 24 lighting hours daily throw the experimental period, which lasted for 6 weeks. All chicks have undergone all the vaccinations recommended in the farm preventive program. Diets were weekly mixed. Feed and water ad-libitum during the starter, grower and the finisher period.

\section{Experimental Diets and Treatments:}

A basal diet was formulated to meet the nutrient requirements according to the nutritional recommendation of Ross 308 strain, The starter diet was used from $0-14 \mathrm{~d}$ which contained $23 \%$ crude protein and 3000 $\mathrm{kcal} \mathrm{ME} / \mathrm{kg}$ diet, followed by grower diet from 15- 28 day which contained $21.5 \%$ crude protein and $3100 \mathrm{kcal} \mathrm{ME} / \mathrm{kg}$ diet . The finisher diet was used from 29 day till the end of the study, which contained $19.5 \%$ crude protein and $3200 \mathrm{kcal} \mathrm{ME} / \mathrm{kg}$ diet. The diets composition and its chemical analysis are shown in (Table, 1$)$.

Sex dietary treatments were made using basal diet:

- Basal diet containing 5\% corn gluten meal (control).

- Basal diet containing $5 \%$ corn gluten meal $+0.1 \%$ hot pepper.

- Basal diet containing $5 \%$ corn gluten meal $+0.2 \%$ hot pepper.

- Basal diet containing 10\% corn gluten meal (control).

- Basal diet containing $10 \%$ corn gluten meal $+0.1 \%$ hot pepper.

- Basal diet containing $10 \%$ corn gluten meal $+0.2 \%$ hot pepper.

\section{Measurements:}

\section{Growth performance:}

Birds' individual body weight and pen feed consumption were written down for growth interval. Also, mortality was daily observed. Body weight gains average feed consumption and feed conversion ratio were scored and calculated. 
Table (1): Composition and chemical composition of experimental diets.

\begin{tabular}{|c|c|c|c|c|c|c|}
\hline \multirow{3}{*}{ Ingredients \% } & \multicolumn{6}{|c|}{ Corn gluten meal } \\
\hline & \multicolumn{3}{|c|}{$5 \%$} & \multicolumn{3}{|c|}{$10 \%$} \\
\hline & $\begin{array}{c}\text { Starter } \\
(1-14 \mathrm{~d})\end{array}$ & $\begin{array}{c}\text { Grower } \\
(15-28 \text { d) }\end{array}$ & $\begin{array}{l}\text { Finisher } \\
(29-42 \text { d) }\end{array}$ & $\begin{array}{l}\text { Starter } \\
(1-14 \text { d })\end{array}$ & $\begin{array}{c}\text { Grower } \\
(15-28 \text { d) }\end{array}$ & $\begin{array}{l}\text { Finisher } \\
(29-42 \text { d) }\end{array}$ \\
\hline Yellow corn & 51.88 & 55.33 & 60.51 & 56.52 & 60.55 & 65.90 \\
\hline Soybean meal (44\%) & 36.00 & 32.00 & 26.40 & 27.85 & 23.68 & 18.00 \\
\hline Corn gluten meal $(60 \%)$ & 5.00 & 5.00 & 5.00 & 10.00 & 10.00 & 10.00 \\
\hline Soya oil & 3.2 & 4.10 & 4.70 & 1.35 & 1.93 & 2.49 \\
\hline Di calcium phosphate & 1.76 & 1.56 & 1.35 & 1.90 & 1.60 & 1.40 \\
\hline Lime stone & 1.25 & 1.15 & 1.15 & 1.30 & 1.20 & 1.15 \\
\hline $\mathrm{NaCl}$ & 0.40 & 0.40 & 0.04 & 0.40 & 0.40 & 0.40 \\
\hline Vitamins \& minerals & 0.30 & 0.30 & 0.30 & 0.30 & 0.30 & 0.30 \\
\hline premix & 0.15 & 0.12 & 0.11 & 0.10 & 0.07 & 0.05 \\
\hline Methionine & 0.06 & 0.04 & 0.08 & 0.28 & 0.27 & 0.31 \\
\hline Lysine Hcl & 100 & 100 & 100 & 100 & 100 & 100 \\
\hline Total & & & & & & \\
\hline Calculated analyses: & & & & & & \\
\hline Crude protein \% & 23.07 & 21.55 & 19.51 & 23.12 & 21.57 & 19.51 \\
\hline ME (Kcal/Kg) & 3001 & 3101 & 3201 & 3011 & 3100 & 3200 \\
\hline Crude fiber\% & 3.92 & 3.71 & 3.42 & 3.53 & 3.32 & 3.03 \\
\hline Crude fat $\%$ & 5.82 & 6.79 & 7.51 & 4.13 & 4.81 & 5.48 \\
\hline Calcium \% & 0.97 & 0.88 & 0.82 & 1.00 & 0.89 & 0.81 \\
\hline Av. phosphorus\% & 0.48 & 0.44 & 0.39 & 0.51 & 0.44 & 0.39 \\
\hline L-Lysine \% & 1.28 & 1.16 & 1.04 & 1.27 & 1.15 & 1.03 \\
\hline DL -Methionine\% & 0.57 & 0.52 & 0.48 & 0.56 & 0.51 & 0.47 \\
\hline Meth + Cystine \% & 0.95 & 0.88 & 0.81 & 0.95 & 0.88 & 0.80 \\
\hline Sodium \% & 0.17 & 0.17 & 0.17 & 0.17 & 0.17 & 0.17 \\
\hline
\end{tabular}

*Each $3 \mathrm{~kg}$ of Vit and Min in Premix contain: 12000000IU Vit A, 2000000 IU Vit D3 $10000 \mathrm{mg}$ Vit E,2000mg Vit K, 1000mg Vit.B1, 5000mg Vit B2, 2000mg Vit B6, 10mg Vit B12, 30000mg Niacin, $10000 \mathrm{mg}$ pantothenic acid, 50mg Biotin, 3000mg Folic acid, 250000 $\mathrm{mg}$ choline, 50000mg Zn, 60000mg Mn, 30000mg Fe, 4000mg

$\mathrm{Cu}, 300 \mathrm{mg}$ I , 100mg Se and 100mg Co.

\section{Carcass criteria and intestinal histology:}

At the end of the experiment at 42 days of age, three birds were chosen from each group to be near the average body weight, fasted for eight hours nearly. Selected birds were individually weighed and slaughtered to complete bleeding. Slaughtered birds were used to evaluate carcass characteristics, weight of each eviscerated carcass, edible parts like liver, heart and empty gizzard, were recorded. The abdominal fat was gently removed and weighed and calculated as percentage of live body weight. The dressing percentage was calculated, by dividing the carcass and giblets weights by the pre slaughter live body weight of birds. Also, part of the ileum has been taken $10 \mathrm{~cm}$ long for the histological examination of the intestine villus and crypts. 
Statistical analysis: Data were statistically analyzed using General Linear Models Procedure of the SPSS (2008), differences between treatments were subjected to Duncan's Multiple Range - test (Duncan, 1955). The following model was used to study the effect of treatments on the parameters investigated as follows: $\mathrm{Yij}=\mu+\mathrm{Ti}+$ eij where: $\mathrm{Yij}=$ an observation, $\mu=$ overall mean, $\mathrm{Ti}=$ effect of treatment $(\mathrm{i}$ $=1 \ldots$ and 6 ) and eij $=$ Random error.

\section{RESULTS AND DISCUSSION}

Growth performance: The following results in experiment demonstrate the influence of different levels of corn gluten meal and supplemented with hot pepper on growth performance of broiler chicks.

\section{Live body weight:}

The initial and average live body weight at 2, 4 and 6 weeks of age are illustrated in Table (2). The differences initial live weight between treatment groups were not significant. Accordingly, this may create suitable condition to appraise the effect of dietary treatments during the subsequent periods of starter and growth. When the chicks were fed different levels of corn gluten meal (CGM), the body weights among the various treatments varied significantly $(\mathrm{P}<0.01)$ at 2 and 4 weeks of age. At both age, the chicks fed low level of corn gluten meal diet (control, 5\% CGM) weighed significantly $(\mathrm{P}<0.01)$ more than those fed the high corn gluten meal level diet (control, 10\% CGM).While, no such difference occurred between the chicks fed on hot pepper diets. However, this trend became more pronounced in that birds fed hot pepper diets were significantly $(\mathrm{P}<0.01)$ heavier than those birds fed control ( $10 \%$ CGM), while no difference was observed from control diet (5\%). At 6 weeks of age, between the levels of dietary corn gluten meal, control (5\% CGM) had a significantly $(\mathrm{P}<0.05)$ higher live body weight than control $(10 \%$ CGM). A similar observation was noted for the source of local natural feed additives. Chicks fed diets containing hot pepper $(0.1 \%$ with $5 \%$ CGM), hot pepper $(0.2 \%$ with $5 \%$ CGM $)$ and hot pepper $(0.2 \%$ with $10 \%$ CGM) recorded the heaviest $(\mathrm{P}<0.05)$ body weight $(2112,2131$ and $2098 \mathrm{~g}$, respectively), with insignificant differences between each other. However, chicks fed diets containing hot pepper (0.1\% and 10\% CGM), and control (10\% CGM) had the lower body weight (2047 and $1996 \mathrm{~g}$, respectively), with significant $(\mathrm{P}<0.01)$ difference between either control (5\% CGM) or another hot pepper groups. 
Table (2): Effect of hot pepper and corn gluten meal on growth of broiler chicks.

\begin{tabular}{|c|c|c|c|c|c|c|c|c|}
\hline \multirow[t]{2}{*}{ Experimental diets } & \multicolumn{4}{|c|}{ Body weight (g) } & \multicolumn{4}{|c|}{ Body weigt gain (g) } \\
\hline & Initial & 2wks & 4 wks & $6 \mathrm{wks}$ & 1-2 wks & $2-4$ wks & 4-6 wks & 1-6 wks \\
\hline & \multicolumn{8}{|c|}{ Corn Gluten Meal (5\%) } \\
\hline Control & 40.32 & $351^{\mathrm{a}}$ & $1066^{\mathrm{ab}}$ & $\mathbf{2 1 1 0}^{\mathrm{a}}$ & $310.7^{\mathrm{a}}$ & 715 & 1044 & $2069.7^{\mathrm{a}}$ \\
\hline Hot Pepper (0.1\%) & 40.52 & $352^{\mathrm{a}}$ & $1076^{\mathrm{a}}$ & $2112^{\mathrm{a}}$ & $311.5^{\mathrm{a}}$ & 724 & 1036 & $2071.5^{a}$ \\
\hline \multirow[t]{2}{*}{ Hot Pepper (0.2\%) } & 40.28 & $354^{\mathrm{a}}$ & $1074^{\mathrm{a}}$ & $2131^{\mathrm{a}}$ & $313.7^{\mathrm{a}}$ & 720 & 1057 & $2090.7^{\mathrm{a}}$ \\
\hline & \multicolumn{8}{|c|}{ Corn Gluten Meal $(10 \%)$} \\
\hline Control & 40.40 & $334^{\mathrm{b}}$ & $1012^{b}$ & $1996^{c}$ & $293.6^{b}$ & 678.0 & 984 & $1955.6^{\mathrm{c}}$ \\
\hline Hot Pepper (0.1\%) & 40.39 & $344^{\text {ab }}$ & $1043^{\mathrm{ab}}$ & $2047^{\text {bc }}$ & $303.61^{\text {ab }}$ & 699.0 & 1004 & $2006.6^{\text {bc }}$ \\
\hline Hot Pepper ( & 40.31 & $352^{\mathrm{a}}$ & $1069^{\mathrm{ab}}$ & $2098^{a b}$ & $311.7^{\mathrm{a}}$ & 717 & 1029 & $2057.7^{\mathrm{ab}}$ \\
\hline & 0.24 & 5.64 & 21.07 & 27.88 & 5.66 & 21.95 & 35.89 & 27.89 \\
\hline \multicolumn{9}{|c|}{ Probability $(\mathbf{p}<)$} \\
\hline Significance & NS & 0.004 & 0.019 & 0.001 & 0.004 & NS & NS & 0.001 \\
\hline
\end{tabular}

${ }^{\text {a-c }}$ Means within columns with no common superscript differ significantly $(p<0.05)$.

\section{Body weight gain:}

Body weight gains were affected by level of CGM and hot pepper addition in the diet (Tables, 2). At 1-2 weeks of age, the weight gain was the highest in control group (5\% CGM) compared to control group (10\% $\mathrm{CGM}$ ), which did differ significantly $(\mathrm{P}<0.01)$. At this age, the chicks fed on the hot pepper $(0.1 \%$ with $5 \% \mathrm{CGM})$, and hot pepper diets $(0.2 \%$ with $5 \%$ or $10 \%$ CGM $)$ had significantly $(\mathrm{P}<0.01)$ heavier body weight gain than birds in hot pepper group ( $0.1 \%$ with $10 \%$ CGM). At 2-4 and 4-6 weeks of age, there were no significant differences in body weight gain between the chicks fed various levels of corn gluten meal( controls) and hot pepper diets. Body weight gain at 1- 6 weeks of age of chicks fed diets contained low or high corn gluten meal level (controls) was found to be 2069.7 and $1955.6 \mathrm{~g}$, respectively, the differences were significant $(\mathrm{P}<$ 0.01 ). Between local natural feed additives, hot pepper ( 0.1 or $0.2 \%$ with $5 \%$ CGM), hot pepper ( $0.2 \%$ with $10 \%$ CGM) and control diets ( $5 \%$ CGM) had a significantly $(\mathrm{P}<0.01)$ higher body weight gain than hot pepper $(0.1 \%, 10 \% \mathrm{CGM})$ and control ( $5 \%$ CGM), which did not differ significantly from each other.

Our results in this experiment showed that live body weight was affected by level of corn gluten meal in the control diets at 2, 4 and 6 weeks of age. Whereas, body weight gain were affected by level of corn gluten meal during the starter and overall experiment period, except in the grower and finishing stages (Table, 2). Consequently, several instances could suggested to explain these findings. Ismail et al. (2005) reported that increasing dietary CGM beyond 9\% adversely affected broiler chicks growth performance and weight gain reduced a little with increasing the CGM supplementation in diets. Afrouzi et al.(2018) indicated that treatments containing $2 \%$ corn gluten meal with protease enzyme processing at different times, increased body weight gain vs. $2 \%$ corn gluten meal 
without enzymatic processing. Qaisrani, (2014) compared three protein sources: soybean meal (SBM), rapeseed meal (RSM) and maize gluten meal (MG), and two digestible crude protein (DCP) levels: 15.8 and 17.2\%. Broilers fed SBM had greater BW gain $(\mathrm{P}<0.001)$ compared with those fed RSM and MG diets. The low N digestibility of the RSM and MG diets compared to the SBM diet has led to an increase in $\mathrm{N}$ in the hindgut. This indigestible protein may stimulate protein fermentation, which coincides with poor performance and reduced gut health. He et al.(2018) evaluated the protein bioavailability of hydrolysed corn gluten meal using the protein efficiency ratio method, and the results indicated that the protein efficiency ratio of the hydrolyses corn gluten meal (HCGM) group was 1.72 times higher than that of the crude corn meal(CCGM) group. Furthermore, there was a significant difference in the body weight increase between the HCGM and CCGM groups. Continuous dietary administration of hot pepper significantly affected on live body weight and body weight gains at 2 weeks of age (Table 2). Whereas, no significant differences in either live body weights or body weight gain at 2-4 and 4-6 weeks of age. The supplementation of hot pepper in the diets is widely supported view suggested by Williams and Kienholz (1974) who found that several levels of chili powder $(0,1.5,3,6$ and $12 \%$, respectively) had little effect on growth broiler of chicks at 27 days of age, except that the $12 \%$ level significantly reduced growth to $84 \%$ of control bird growth. Tellez et al (1993) suggested that providing dietary capsaicin during the first 14 or 19 days of live causes no apparent change in body weight gain of broiler chicks. McElroy et al. (1994) found that continuous dietary administration of capsaicin did not significantly affect body weight of broiler chicks at 21 days of age. An interesting aspect of the experiment was the effect of hot pepper on growth of broiler chicks at 6 weeks of age (Table 2). Addition of hot pepper to low and high corn gluten level diets had significantly heavier live body weight and body weight gain in comparison with hot pepper $(0.1 \%$ with $10 \%$ CGM) and control (10\% CGM) diets. These results are in agreement with Azouz (2001) who stated that, the levels of 1, 1.5 and 2\% of hot pepper in the diets improved significantly body weight gain. Similar results by Soliman and Al-Afifi (2020) were reported that, the chicks of the first group were fed basal diet (control) and the other three groups were fed the basal diet supplemented with three levels of red pepper as $0.5 \%, 1.0 \%$ and $2.0 \%$. Body weight, body weight gain and feed conversion ratio improved significantly due to feeding different graded levels of hot pepper. El-Tazi (2014) reported that, inclusion of hot red pepper in the diet at levels of 0.5 , $0.75,1 \%$ improved significantly the body weight gain and feed efficiency of broiler chicks. Results of present study are equally in harmony with the findings of Kolawole et al. (2017) who found that, the performance at the end of 7th week showed that daily body weight gain for birds fed diets with 
different levels of hot red pepper $(0.1,0.2$ and $0.3 \%)$ were significantly $(\mathrm{p}<$ $0.05)$ higher than obtained for those on control diet. There are a few researches works proving that, an increase in the level of corn gluten at $10 \%$ in broiler diets has a negative effect on body weight and the weight gain. There is also a dearth of researches which showing the effect of adding chili peppers in broiler diets containing high levels of corn gluten powder. $\operatorname{Azouz}(\mathbf{2 0 0 1})$ fed broiler chicks on control diets containing 18.68\% ( starter stage) and $13.55 \%$ (finisher stage) of corn gluten meal compared to broiler chicks fed on diets containing $20.86 \%$ ( starter stage) and $15.69 \%$ (finisher stage) of corn gluten meal supplemented with $1 \%$ hot pepper, respectively . The results showed that a significant $(\mathrm{P}<0.01)$ increased in body weight and body weight gained in groups that were fed hot peppers when compared to the control groups.

\section{Mortality Rate:}

Throughout of the experiment period, the mortality rate was negligible. Post-mortem investigation indicated no relationship between dietary and mortality rate. This was in line with the finding of Azouz (2001) who found that the addition of hot red pepper to diet at 1, 1.5 and $2 \%$ did not significantly effect on mortality rate. Williams and Kienholz (1974) concluded that chili powder at 1.5, 3, 6 and $12 \%$ of diet, had no effect on mortality of broiler chicks. This is may be due to natural occurring biological active components in herbs are generally assumed to be more acceptable and a rich sources of potential disease control when added at suitable doses El- Amin et al.(2015).

\section{Feed Intake:}

Table (3) provides a breakdown of the intakes diets at 1-2, 2-4 , 4-6 and 1-6 weeks of age. Chicks fed on the low and high corn gluten meal diets (controls) consumed significantly $(\mathrm{P}<0.01)$ more feed intake than those fed on hot pepper diets for 1-2 weeks. In the same age, chicks fed on hot pepper (0.2\% with 5\% CGM) diets consumed significantly ( $\mathrm{P}<0.01)$ less feed intake than those fed on hot pepper diets $(0.1 \%$ with $5 \%$ CGM or $10 \%$ CGM and $0.2 \%$ with $10 \%$ CGM ), which did not differ significantly from each other. While, at 2-4 weeks of age, birds fed hot pepper diets had significantly $(\mathrm{P}<0.01)$ less feed intake than those receiving control diets (10\% CGM). The difference became more pronounced especially for those fed hot pepper ( $0.2 \%$ with 5\% CGM) and the value were significantly lower $(\mathrm{P}<0.01)$ than birds of all other treatment groups. At 4-6 weeks, there was no significant differences between different levels of hot pepper diets and low and high corn gluten diets ( controls) for feed intake. The highest feed intake value was $1832 \mathrm{~g}$ for control (10\% CGM) diet and the lowest value was $1745 \mathrm{~g}$ for hot pepper $(0.2 \%$ with $5 \% \mathrm{CGM})$. As dietary hot pepper level increased, feed intake decreased linearly for 1-6 weeks of age. The feed intake value for hot pepper diets was significantly $(\mathrm{P}<0.01)$ less than those 
of control diets (10\% CGM), which did not differ significantly from each other The feed intake value for hot pepper diet ( $0.2 \%$ with 5\% CGM) was significantly $(\mathrm{P}<0.01)$ less than hot pepper diets $(0.1 \%$ or $0.2 \%$ with $10 \%$ CGM) which did not differ significantly from each other. While, no such difference occurred between the chicks fed on low level of corn gluten meal (5\%) supplemented with the low or high level of hot pepper $(0.1 \%$ or $0.2 \%$ ), except chicks fed hot pepper $0.1 \%$ with 5\% CGM. The results in this experiment showed that feed intake was unaffected by level of corn gluten meal in the control diets, in contrast, feed intake was affected by levels in hot pepper diets (Table, 3). In agreement with Rose et al. (2003) who demonstrated a significant increase in feed intake when broiler chicks were fed a diet containing 10\% CGM. Increasing of hot pepper, reported that the feed intake reduced significantly $(\mathrm{P}<0.01)$ with increased level of hot red pepper incorporation up to $0.4 \% \%$ in the quail diet as compared to those fed the control diet. Afolabi et al.(2017) revealed that the inclusion of hot red pepper at levels of $0.3 \%$ in the diets of broiler chicken decreased feed intake. The same trend with previous studies, Azouz (2001) reported that feed intake of broiler decreased as the level of hot red pepper increased to $2 \%$.

They attributed that to the addition of capsaicin to the diet may affected energy metabolism by activating the sympathetic nervous system (SNS) in animals (Kawada et al.,1988).

\section{Feed Conversion ratio:}

Feed conversion at 1-2, 2-4, 4-6 and 1-6 weeks of age are illustrated in Table (3). Feed conversion ratio over the experimental period of 1-2 weeks shows that birds fed hot pepper ( $0.2 \%$ with $5 \%$ CGM), hot pepper $(0.1 \%$ with $10 \%$ CGM) and hot pepper (0.2\% with $10 \%$ CGM) were more efficient $(\mathrm{P}<0.01)$ than birds fed the control diets $(5 \%$ or $10 \%$ CGM) and hot pepper ( $0.1 \%$ with $10 \%$ CGM). At 2 - 4 weeks of age, this trend became pronounced in those birds fed 10\% corn gluten diet (control) were significantly $(\mathrm{P}<0.01)$ less efficient in terms of feed utilization. However, feed conversion for birds offered diets of hot pepper $(0.2 \%$ with $5 \%$ CGM) responded by being significantly $(\mathrm{P}<0.01)$ most efficient in terms of feed utilization. There was no significant between local natural feed additives( hot pepper) and levels of dietary corn gluten meal (controls) for feed conversion at 4-6 weeks. Chicks fed on the high corn gluten meal diet $(10 \%)$ utilized the feed less efficient $(\mathrm{P}<0.01)$ than chicks fed on the low level of corn gluten meal diet ( 5\%) and hot pepper diets at 1-6 weeks of age. At this age, the chicks fed on the hot pepper $(0.2 \%$ with $5 \%$ CGM) were most efficient, followed by those chicks fed hot pepper $(0.1 \%$ with 5 CGM) and hot pepper $(0.2 \%$ with $10 \%$ CGM), whereas chicks fed the diet containing hot pepper $(0.1 \%$ with $10 \%$ CGM) were the least efficient $(\mathrm{P}<$ $0.01)$. 
Table(3): Effect of hot pepper and corn gluten meal on feed intake and feed conversion of broiler chicks.

\begin{tabular}{|c|c|c|c|c|c|c|c|c|}
\hline \multirow[t]{2}{*}{ Experimental diets } & \multicolumn{4}{|c|}{ Feed Intake (g) } & \multicolumn{4}{|c|}{ Feed conversion (g) } \\
\hline & $1-2$ wks & 2-4 wks & 4-6 wks & $1-6 \mathrm{wks}$ & $1-2$ wks & $2-4$ wks & 4-6 wks & $1-6 \mathrm{wks}$ \\
\hline & \multicolumn{8}{|c|}{ Corn Gluten Meal (5\%) } \\
\hline Control & $379^{\mathrm{a}}$ & $1214^{\mathrm{ab}}$ & 1806 & 3399 $^{\text {ab }}$ & $1.22^{\mathrm{b}}$ & $1.70^{b}$ & 1.73 & $1.64^{\mathrm{bc}}$ \\
\hline Hot Pepper (0.1\%) & $340^{\mathrm{bc}}$ & $1158^{\text {cd }}$ & 1749 & $3247^{\text {cd }}$ & $1.09^{d}$ & $1.60^{\mathrm{bc}}$ & 1.69 & $1.57^{\mathrm{cd}}$ \\
\hline \multirow[t]{2}{*}{ Hot Pepper (0.2\%) } & $3^{3} 5^{\mathrm{c}}$ & $1136^{\mathrm{d}}$ & 1745 & $3216^{\mathrm{d}}$ & $1.07^{\mathrm{d}}$ & $1.58^{\mathrm{c}}$ & 1.65 & $1.54^{\mathrm{d}}$ \\
\hline & \multicolumn{8}{|c|}{ Corn Gluten Meal (10\%) } \\
\hline Control & $\mathbf{3 8 5}^{\mathrm{a}}$ & 1239 $^{\mathrm{a}}$ & 1822 & $3446^{\mathrm{a}}$ & $1.31^{\mathrm{a}}$ & $1.83^{\mathrm{a}}$ & 1.83 & $1.77^{\mathrm{a}}$ \\
\hline Hot Pepper (0.1\%) & $349^{b}$ & $1182^{\mathrm{bc}}$ & 1805 & 3336 $^{\text {be }}$ & $1.15^{\mathrm{c}}$ & $1.69^{\mathrm{bc}}$ & 1.80 & $1.67^{\mathrm{b}}$ \\
\hline Hot Pepper (0.2\%) & $348^{b}$ & $1180^{\mathrm{bc}}$ & 1800 & $3328^{\text {bc }}$ & $1.12^{\mathrm{cd}}$ & $1.65^{\mathrm{bc}}$ & 1.75 & $1.62^{\mathrm{bc}}$ \\
\hline Pooled SE & 4.74 & 18.78 & 33.44 & 45.52 & 0.026 & 0.056 & 0.071 & $\mathbf{0 . 0 3 2}$ \\
\hline \multicolumn{9}{|c|}{ Probability $(\mathbf{p}<)$} \\
\hline Significance & 0.001 & 0.001 & NS & 0.001 & 0.001 & 0.002 & NS & 0.001 \\
\hline
\end{tabular}

${ }^{\mathrm{a}-\mathrm{d}}$ Means within columns with no common superscript differ significantly $(\mathbf{p}<0.05)$.

Consequently, several instances could be proposed to explain these findings. Ismail et al. (2005) who studied the effect of feeding graded levels of maize gluten meal ( $3,6,9,12,15 \%$, respectively), indicated that, the broiler fed on ration contained 9\% maize gluten meal (MGM) recorded maximum feed efficiency with significantly better feed conversion as compared to rest of the treatments or control. The increase in MGM over 9\% had no economic effect on feed conversion ratio even feed conversion ratio was reduced with increasing MGM supplementation. Qaisrani et al. (2020) explained that feed conversion was affected $(\mathrm{P}<0.001)$ by protein sources, indicating that broilers fed the soybean diet had an improved feed conversion (1.51) compared with those fed the rape seeds (1.63) and corn gluten meal (1.61) diets. There are several factors that explain, the reason of poor effect in the high level of corn gluten (10\%) in feed conversion ratio of the present study. Qaisrani (2014) found that low protein digestibility in a diet means less amino acids were available for growth and potentially larger amounts of indigestible $\mathrm{CP}$ could enter the hindgut, leading to proteolytic fermentation. Moreover, processing and excretion of nitrogenous compounds require more energy, resulting in less energy availability for growth. Reid and Hillman (1999) reported that undigested protein substances may stimulate the growth of $\mathrm{N}$ utilising microbiota. Leading to increased levels of toxic compounds, such as biogenic amines, phenols, and cresols (Apajalahti and Vienola 2016). These toxic compounds may be detrimental for bird performance and gut health (Thomke and El winger 1998). The shorter villi with greater crypt depth in broilers fed RSM and MG diets may be an indication of more damage to the gut by harmful compounds produced by microbial fermentation. A deeper crypt indicated 
increased turnover of enterocytes and, thus, more protein and energy demand for this purpose (Qaisrani et al., 2020).

The study has shown that the addition of hot red pepper had a positive effect on feed conversion results of chickens which is also in agreement with previous findings of

Azouz (2001) who stated that, the levels of 1, 1.5 and $2 \%$ of hot pepper in the diets improved significantly feed conversion. Al-Kassie $\boldsymbol{e t}$ al. (2011) revealed that the inclusion of hot red pepper at levels of $0.5 \%, 0.75 \%$ and $1 \%$ in the diets of broiler chicks improved feed conversion. El-amin (2015) indicated feed conversion showed a significant $(\mathrm{P}<0.05)$ improvements in chicks that fed on the diets supplemented with hot red pepper at various levels ( $0.5,1$ or $1.5 \%$, respectively) impaired with those feed on control diet. Soliman and Al-Afifi (2020) observed an enhancement in feed conversion ratio due to inclusion $2 \%$ hot pepper into broiler diets. The current results especially of $0.1 \%$ hot pepper with high level of corn gluten meal (10\%) are equally in harmony with the findings of Kolawole $\boldsymbol{e t}$ al. ( 2017) who stated that, feed conversion for broiler chicken fed diets with hot red pepper $(0.2 \%$ or $0.3 \%)$ were improved significantly $(\mathrm{p}<0.05)$ than obtained by those on control and hot pepper $(0.1 \%)$ diet. The mode of beneficial action of hot pepper may be related to its effect in improving the nutrients utilization via increase villi length and reduce the count of harmful bacterial strains. Shahverdi et al. (2013) reported that adding red or black pepper into broiler diets can modify the morphology of small intestine by reducing the growth of pathogenic or nonpathogenic intestinal organisms. These reductions in pathogenic bacteria reduce the inflammatory reactions at the intestinal mucosa leads to the increase of the villus area and improve functions of secretion, digestion and nutrients absorption (Cardoso et al., 2012). Moreover, Villi length significantly $(\mathrm{P} \leq 0.05)$ improved due to adding hot red pepper by into diets. Villi length increment was associated with significant reduction in crypt depth (Soliman and Al Afifi, 2020) .

\section{Carcass characteristics:}

Body weight to prior to slaughtering, dressing $\%$, liver $\%$, gizzard $\%$, heart $\%$ and abdominal fat are presented in Table (4). Consequently, body weight and dressing as percentages of live body weight were significantly heavier $(\mathrm{P}<0.01)$ when birds fed hot pepper and low corn gluten meal (5\%) diets than birds fed high level of corn gluten $(10 \%)$ and hot pepper diets ( $0.2 \%$ with $10 \%$ CGM). Moreover, the diets with hot pepper resulted in a significantly decreased $(\mathrm{P}<0.01)$ liver percentage than control diets. There were no significant differences in gizzard and heart percentages for chicks fed diet containing hot pepper and low and high level of corn gluten meal (controls). Abdominal fat percentage decreased $(\mathrm{P}<0.01)$ linearly with a decrease level of corn gluten meal in diet $(5 \%)$. Hot 
pepper diets had the lower abdominal fat $\%(\mathrm{P}<0.01)$ than control diets. Moreover, there were no significant different among hot pepper diets. The result obtained from this study corroborates with the reports of Seyedi and Hosseinkhani (2014) showed that CGM incorporation in broiler diets at low amounts (up to 6 percent of diet) had no effect on performance or carcass characteristics. Rose et al. (2003) have also reported well comparable result, which supplemented varied CGM levels in broiler ration and found increase carcass fat. Ismail et al. (2005) reported that CGM supplementation in broiler diets had an adverse effect on carcass traits . It can be due to amino acids imbalance, reduction of lysine consumption, reduction of protein consumption and imbalanced ratio of energy to amino acids which are followed by considerable fat deposit in abdomen. Hot pepper diets had significantly higher dressing percentage than those birds fed either controls or hot diet (0.2\% with $10 \%$ CGM). These results are equally with the findings of Azouz (2001) and ElAmin (2015).

Table (4): Effect of hot pepper and corn gluten meal on carcass yields of broiler chicks.

\begin{tabular}{|c|c|c|c|c|c|c|}
\hline \multirow[t]{3}{*}{$\begin{array}{l}\text { Experimental } \\
\text { diets }\end{array}$} & \multirow[t]{2}{*}{$\begin{array}{c}\text { Body weight } \\
\text { (g) }\end{array}$} & Dressing & Liver & Gizzard & Heart & $\begin{array}{c}\text { Abdominal } \\
\text { fat }\end{array}$ \\
\hline & & \multicolumn{5}{|c|}{$\%$} \\
\hline & \multicolumn{6}{|c|}{ Corn Gluten Meal (10\%) } \\
\hline Control & $2120^{\mathrm{a}}$ & $68.50^{b}$ & 3.07 & 1.68 & $\mathbf{0 . 5 3}$ & $2.04^{b}$ \\
\hline Hot Pepper (0.1\%) & $2122^{\mathrm{a}}$ & $69.23^{\mathrm{ab}}$ & 3.12 & 1.63 & 0.52 & $1.82^{c}$ \\
\hline \multirow[t]{2}{*}{ Hot Pepper (0.2\%) } & $2156^{\mathrm{a}}$ & $70.80^{\mathrm{a}}$ & 2.97 & 1.61 & $\mathbf{0 . 5 3}$ & $1.72^{\mathrm{c}}$ \\
\hline & \multicolumn{6}{|c|}{ Corn Gluten Meal (10\%) } \\
\hline Control & $2010^{c}$ & $65.69^{c}$ & 2.99 & 1.75 & 0.55 & $2.33^{\mathrm{a}}$ \\
\hline Hot Pepper (0.1\%) & $2052^{\text {bc }}$ & $68.06^{b}$ & 2.93 & 1.72 & 0.54 & $1.87^{\mathrm{c}}$ \\
\hline Hot Pepper (0.2\%) & $2102^{\mathrm{ab}}$ & $69.16^{\mathrm{ab}}$ & 3.06 & 1.67 & 0.55 & $1.78^{c}$ \\
\hline Pooled SE & 13.14 & 0.44 & 0.05 & 0.02 & 0.01 & 0.04 \\
\hline \multicolumn{7}{|c|}{ Probability $(\mathbf{P}<)$} \\
\hline Significance & 0.001 & 0.005 & NS & NS & NS & 0.001 \\
\hline
\end{tabular}

${ }^{a-c}$ Means within columns with no common superscript differ significantly $(\mathrm{p}<0.05)$.

Who stated that, the addition of hot red pepper at level $1 \%$ and $1.5 \%$ in the diet increased significantly the dressing percentage. Similarly El-Tazi (2014) found that, birds fed on the highest level of hot pepper on $1 \%$ was significantly increased the dressing percentage when compared with the control group. Islam et al.(2018) reported that the highest dressing percentage was recorded in broiler fed ration with $0.5 \%$ red chili. Hot red pepper supplementation did not affect the of liver, heart and gizzard weight percentage. These results are in consist with those of Azouz (2001), Islam et al. (2018), and Soliman and Al-Afifi (2020). Significantly lower abdominal fat percentage were recorded for chicks fed on hot pepper diets. This result was in line with finding reported by Azouz (2001) who found that addition of hot pepper 
powder in the diet significantly decreased the abdominal fat in broilers. The reduction in abdominal fat of chick fed hot pepper may be due to capsaicin which may possess lipids lowering effect. However the mechanisms of reducing abdominal fat by the herbs feed additives may be through increasing the secretion of lipase and secondary bile acids. Which reducing accumulation of fatty acids in abdominal cavity (El-Amin, 2015).

\section{Intestinal histomorphology:}

Hot pepper influenced $(\mathrm{P}<0.001$ and $\mathrm{P}<0.05)$ intestinal histomorphology. Villus length were 40.29 and $40.77 \%$ greater, whereas crypt depths were 9.57 and $15.11 \%$ smaller in hot pepper $0.1 \%$ or $0.2 \%$ with $5 \%$ corn gluten meal diets fed birds compared with those fed control diet (5\% CGM), respectively (Table 5 ). In the same trend, villus length were 24.54 and $38.42 \%$ greater in the hot pepper $0.1 \%$ or $0.2 \%$ fed birds compared with those fed control diet (10\% CGM), respectively. whereas crypt depths were $14.3 \%$ smaller in hot pepper $0.2 \%$ diet fed birds compared with those fed $10 \%$ corn gluten meal diet (control).Villus length or crypt depths were not significantly differed between corn gluten meal levels (controls). In agreement with early study by Azouz (2001), who showed that sever pathological lesions of proventriculus, gizzard, small intestine and liver in control diets, especially with the higher energy levels compared with hot pepper and fenugreek diets. These observations could explain the negative effect on the performance and the reduction of digestibilities of nutrients observed in birds fed high energy level (control diets containing high levels of corn gluten). The plausible explanation for this fact, in relation to the high level of corn gluten meal in control diets, especially with the high energy level. In the same trend, Qaisrani et al. (2020) reported that the shorter villus height and greater crypt depth in broilers fed rape seed meal and corn gluten meal diets may be an indication of more damage to the gut by harmful compounds produced by microbial fermentation. These shorter villi indicate reduced intestinal health. A shorter villus height may decrease the surface area for absorption of nutrients from the gut as villi are the functional units of nutrient absorption (Zang et al., 2009). A high crypt depth means an increased turnover rate of enterocytes and thus more protein and energy demand for this purpose. Crypt depth is an indicator of the number of crypt cells produced (Hampson, 1986). It has been reported that broilers spend approximately $12 \%$ of synthesized protein on gastrointestinal tract turnover (Choct, 2009). An increase in villus height may enhance nutrient transport across the villus surface, as suggested by Tufarelli et al. (2010) in rabbits. Bai et al. (2019) showed than corn gluten meal exerted negative effects on the intestinal health in turbot, including the induction of enteritis in the DI tissue and impaired intestinal immune and antioxidative systems. An 
interesting aspect of the present work was the intestinal histomorphology alteration of broiler chicks, the best results obtained with hot pepper groups, especially the birds received $0.2 \%$ hot pepper with low level of corn gluten meal ( $5 \%$ ). It is confirmed by Azouz (2001) showed the morphology of small intestine alteration of broiler chicks, the best results for villi length obtained with hot pepper groups, especially the birds received $2 \%$ hot pepper. Prakash and Srinivasan (2010) reported that Wistar rats fed black pepper, red pepper or ginger diets generally induced an increase in microvilli length. Among the test spices, capsaicin produced the maximum increase of $33 \%$, followed by piperine and ginger $(10 \%)$. A prominent increase in the perimeter of the villi was also observed. Among the test spices, capsaicin produced the maximum increase (29\%), followed by ginger $(14 \%)$ and piperine (12\%). Madhupriya et al. (2018) who stated that, phytogenic feed additive derived from capsaicin affect villi height and crypt depth in the jejunum of chicks. Soliman and Al-Afifi (2020) showed that villi length significantly $(\mathrm{P}<0.05)$ improved due to adding hot red pepper by $0.5 \%$ and $1 \%$ into diets. Villi length increment was associated with significant reduction in crypt depth.

It is generally believed that red pepper used for increase bioavailability of corn gluten meal by two pathways, Shahverdi $\boldsymbol{e t}$ al. (2013), reported that adding red or black pepper into broiler diets can modify the morphology of small intestine by reducing the growth of pathogenic or nonpathogenic intestinal organisms. These reductions in pathogenic bacteria reduce the inflammatory reactions at the intestinal mucosa leads to the increase of the villus area and improve functions of secretion, digestion and nutrients absorption (Cardoso et al., 2012) . The other way, red pepper or capsaicin stimulated the activities of intestinal brush-border membranes (BBM) enzymes (glycyl-glycine dipeptidase, leucine amino peptidase and $\gamma$-glutamyl transpeptidase) in the jejunal mucosa, suggesting a modulation in membrane dynamics due to the a polar spice bioactive compound interacting with surrounding lipids and hydrophobic portions in the protein vicinity, which may decrease the tendency of membrane lipids to act as steric constraints to enzyme proteins and thus modify enzyme conformation.

Scanning electronic microscopy of the intestinal villi in red pepper treatments revealed alterations in the ultra-structure, especially an increase in microvilli length and perimeter which would mean a beneficial increase in the absorptive surface of the small intestine, providing for an increased bioavailability of micronutrients (Srinivasan, 2015).

In conclusion, corn gluten meal exerted negative effects on the intestinal health, which caused by the shorter villi with greater crypt depth. Resulting, poor growth performances and carcass characteristics of 
broiler chicks, especially with increased level corn gluten meal in the diet. Hot pepper, a natural food product genuinely "functional" contains food components that modulates functions in the body that are relevant to health. Hot pepper increased villi height and decrease crypt depth, resulting in an increased absorptive surface of the small intestine. For these reasons, hot pepper had the best growth performances and carcass characteristics of broiler chicks, except hot pepper $0.1 \%$ with corn gluten meal $10 \%$. The present work directly suggests that strategies to maintain intestinal health should be developed and undertaken when formulating diets containing corn gluten meal for broiler chicks.

Table (5):Effect of hot pepper and corn gluten meal on of microvillar morphology broilers chicks.

\begin{tabular}{|c|c|c|c|c|c|c|c|c|}
\hline \multirow{3}{*}{$\begin{array}{c}\text { Traits } \\
(\mu \mathrm{m})\end{array}$} & \multicolumn{2}{|c|}{ Control } & \multicolumn{4}{|c|}{ Hot pepper } & \multirow{3}{*}{$\begin{array}{c}\text { Pooled } \\
\text { SE }\end{array}$} & \multirow{3}{*}{ Signi. } \\
\hline & $5 \%$ & $10 \%$ & $0.1 \%$ & $0.2 \%$ & $0.1 \%$ & $0.2 \%$ & & \\
\hline & CGM & CGM & $5 \% \mathrm{CGM}$ & $5 \%$ CGM & $10 \%$ CGM & $10 \%$ CGM & & \\
\hline Villi length & $344.5^{c}$ & $338.06^{c}$ & $576.93^{\mathrm{a}}$ & $581.68^{a}$ & $447.98^{b}$ & $548.94^{a}$ & 15.19 & P $<0.001$ \\
\hline Crypt depth & $73.15^{\mathrm{ab}}$ & $84.08^{a}$ & $66.15^{b}$ & $62.10^{b}$ & $72.52^{\mathrm{ab}}$ & $62.21^{\mathrm{b}}$ & 2.15 & $P<0.05$ \\
\hline
\end{tabular}

${ }^{\text {a-c }}$ Means within columns with no common superscript differ significantly $(p<0.05)$

\section{RREFERENCES:}

Afolabi, K.D. ; E. Kelechi ; N. O. Mobolaji and A. R. Olajide (2017). Hot red pepper (Capsicum annum L.) meal enhanced the immunity, performance and economy of broilers fed in phases. Journal of Biology, Agriculture and Healthcare, 7(8): 2224 3208.

Afrouzi, H. N.; N. Torbatinejad; M.S.Shargh and M. Rezaei (2018). Effect of corn gluten meal without processing and processed with protease enzyme at different times on performance, carcass characteristics and some blood parameters in broiler chickens. Animal Production Research., 7(1): 67-80.

Al-Kassie, G.A.M.; M.A.M. Al-Nasrawi and S.J. Ajeena ( (2011). The Effects of Using Hot Red Pepper as a diet Supplement on Some Performance Traits in Broiler. Pakistan Journal of Nutrition, 10 (9):842-845.

Apajalahti, J. and K. Vienola (2016). Interaction between Chicken Intestinal Microbiota and Protein Digestion. Animal Feed Science and Technology 221: 323-330.

Awad, W. A.; K. Ghareeb; S. Abdel-Raheem; and J. Böhm (2009). Effects of dietary inclusion of probiotic and synbiotic on growth performance, organ weights, and intestinal histomorphology of broiler chickens. Poult. Sci., 88:49-56. 
Azouz. H.M.M. (2001). Effect of hot pepper and fenugreek seeds supplementation on broiler diets. $\mathrm{PhD}$ thesis, Faculty of Agriculture, Cairo University.

Bai, N.; M. Gu; M. Lui; Q., Jia; S. Pan and Z. Zhang (2019). Corn gluten meal induces enteritis and decreases intestinal immunity and antioxidant capacity in turbot (Scophthalmus maximus) at high supplementation levels. Plos One., 14(3):1-18.

Cardoso, V.S. ; C.AR. de Lima ; M.E.F. de Lima ; L.E.G. Dorneles and M.G.M. Danelli (2012). Piperine as a phytogenic additive in broiler diets . Pesq. Agropec. Bras., Brasília, 47(4):489-496.

Choct, M. (2009). Managing gut health through nutrition. Br. Poult. Sci., 50: 9-15.

Daniel, K.; A. E. Kelechi ; N.O. Mobolaji ; A. Rotimi and S. Olajide (2017). Hot Red Pepper (Capsicum annum L.) Meal Enhanced the Immunity, Performance and Economy of Broilers Fed in Phases. Journal of Biology, Agriculture and Healthcare, 7 (8): 2224-3208.

Duncan, D. B. (1955). Multiple range and Multiple F tests. Biometrics, 11: $1-42$.

El-Amin, H.M.S.; K.A. Mohamed and M.A. Mukhtar (2015). Effect of hot red pepper (Capsicum frutescens) on performance abdominal fat and blood serum parameters of broiler. J. of Global Biosciences, 4 (5): 2251-2257.

El-Tazi, S.M.A. (2014). Response of broiler chicks to diets containing red hot pepper as natural feed additive. J. of Science and Technology, Omdurman Islamic University, 4(5):81-86.

Hampson, D.J. (1986). Alterations in piglet small intestinal structure at weaning. Res.Vet. Sci., 40:32-40.

He, Y. ; Q. Ch ; Y. Ma ; Y. Pan ; L. J. Yin ; J. Zhou ; Y. Duan; H. Zhang and H. Ma (2018): Bioavailability of corn gluten meal hydrolysates and their effects on the immune system. Czech J. Food Sci., 36: 1-7.

Islam, M.A.; M. E. Haque; M. S. A. Shikhauu; M. J. Uddin; M. N. Uddin; M. T. Islam and M. S. Islam (2018). Effect of red chili and garlic nutrition as feed additives on growth performance of broiler chicken. International Journal of Natural and Social Sciences, 5(3): 16-24.

Ismail, M.; A. Memon; A.A. Solagi; N.N. Ansari and M.I. Rind (2005). Effect of different levels of maize gluten meal on the 
growth performance of broiler chicks. J Anim and Vet Advances 4: $377-380$.

Jamroz, D.; T. Wertelecki ; M. Houszka and C. Kamel(2006). Influence of diet type on the inclusion of plant origin active substances on morphological and histochemical characteristics of the stomach and jejunum walls in chicken. Journal of Animal Physiology and Animal Nutrition., 90: 255-268.

Jin, J. ; H. Ma ; C. Zhou ; M. Luo ; W. Liu ; W. Qu ; R. He ; L. Luo and A.E.G.A.Yagoub (2015): Effect of degree of hydrolysis on the bioavailability of corn gluten meal hydrolysates. Journal of the Science of Food and Agriculture, 95: 2501-2509.

Kawada, T.; S. Sakabe; T.Watanabe; M. Yamamoto; and K. Iwai (1988). Some pungent principles of spices cause the adrenal medulla to secrete catecholamine in anesthetized rats. Proc. Soc. Exp. Biol. Med., 188: 229-233.

Kolawole, D.; A.E. Kelechi; N.O. Mobolaji and A.R. Olajide (2017). Hot red pepper (Capsicum annum L.) meal enhanced the Immunity, performance and economy of broilers fed in phases. Journal of Biology, Agriculture and Healthcare., 7(8): 2224-3208.

Lokaewmanee, K.; K. Yamauchi and N. Okuda (2012). Effects of dietary red pepper on egg yolk color and histological intestinal morphology in laying hens. Journal of Animal Physiology and Animal Nutrition., 90: 255-268.

Madhupriya, V. ; P. Shamsudeen ; G. Raj Manohar ; S. Senthilkumar ; V. Soundarapandiyan and M. Moorthy (2018). Phyto feed additives in poultry nutrition - a review International Journal of Science, Environment and Technology, 7(3): $815-822$.

McEIroy, A.P. ; J.G. Manning ; L.A. Jaeger ; M. Taub ; J.D. Williams and B.M. Hargis (1994). Effect of prolonged administration on dietary capsaicin on broiler growth and Salmonella enteritidis susceptibility. Avian Dis., 38: 329-333.

Prakash, U.N.S. and K. Srinivasan (2010). Beneficial influence of dietary spices on the ultrastructure and fluidity of intestinal brush border in experimental rats. Br. J. Nutr., 104: 31-39.

Qaisrani, S.N.(2014). Improving performance of broilers fed lower digestible protein diets. $\mathrm{PhD}$ thesis, Wageningen University, Wageningen, NL. 
Qaisrani, S.N.; M. M. Van Krimpen; M. W. A. Verstegen; W. H. Hendriks and R. P. Kwakkel (2020). Effects of three major protein sources on performance, gut morphology and fermentation characteristics in broilers. British Poultry Sci., 61:(1) 43-50.

Reid, C. A. and K. Hillman (1999). The Effects of Retrogradation and Amylose /amylopectin Ratio of Starches on Carbohydrate Fermentation and Microbial Populations in the Porcine Colon. Animal Science., 68: 503-510.

Rose, S.P.; V.R. Pirgozliev ; J. Countney and S.D. Hare (2003). dietary protein source and lysine balance on the efficiency of energy utilization in broiler chickens. International symposioum, rostock warnemunde, germany. 227-230.

Seyedi, A.H. and A. Hosseinkhani (2014). Evaluation Corn Gluten Meal Nutritive Value for Broiler Chicks Arash Hassanzadeh. Int. J. Adv. Biol. Biom. Res., 2 (9): 2609-2615.

Shahverdi, A. ; F. Kheiri ; M. Faghani ; Y. Rahimian and A. Rafiee (2013). The effect of use red pepper (Capsicum annum L) and black pepper (Piper nigrum L) on performance and hematological parameters of broiler chicks. European Journal of Zoological Research., 2: 44- 48.

Singh, S. and M.B. Mandal (2015). Capsaicin and gut motility. International J. of Life Sci. and Pharmacology Res., 5 (2):46-53.

Soliman, N. K. and Sh. F. AlAfifi (2020). The productive performance, intestinal bacteria and histomorphology of broiler chicks fed diets containing hot red pepper. Egypt. Poult. Sci.,40 (I): (345-357).

Srinivasan, K. (2015). Biological activities of red pepper (Capsicum annuum) and its pungent principle capsaicin: A review. Critical Reviews in Food Science and Nutrition 56(9): 1488-1500.

SPSS.(2008). SPSS User's Guide Statistics. Ver. 17. Copyright SPSS Inc., USA.

Tellez, Guillermo ; Laurie A Jaeger ; C.E. Dean and D.E. Corrier (1993): Effect of Prolonged Administration of Dietary Capsaicin on Salmonella enteritidis Infection in Leghorn Chicks. Avian Diseases., 37(1):143-8

Thomke, S. and K. El winger (1998). Growth Promotants in Feeding Pigs and Poultry. III. Alternatives to Antibiotic Growth Promotants. Animal Research., 47: 245 -271. 
Egypt. J. of Appl. Sci., 35 (5) 2020

Tufarelli, V. ; S. Desantis ; S. Zizza and V. Laudadio (2010). Performance, gut morphology and carcass characteristics of fattening rabbits as affected by particle size of pelleted diets. Arch. Anim. Nutr., 64:373-382.

Usha, N. S. Prakash and K. Srinivasan (2010). Beneficial influence of dietary spices on the ultrastructure and fluidity of the intestinal brush border in rats. British Journal of Nutrition, 104: 31-39.

Williams, N. and W. Kienholz (1974): The effect of chili, curry and black pepper powders in diets for broiler chicks. Poult. Sci., 53: 2233-2234.

Zang, J. J.; X. S. Piao; D. S. Huang; J. J. Wang; X. Ma and Y. X. Ma (2009). Effects of feed particle size and feed form on growth performance, nutrient metabolizability and intestinal morphology in broiler chickens. Asian-Aust. J. Anim. Sci., 22(1):107-112.

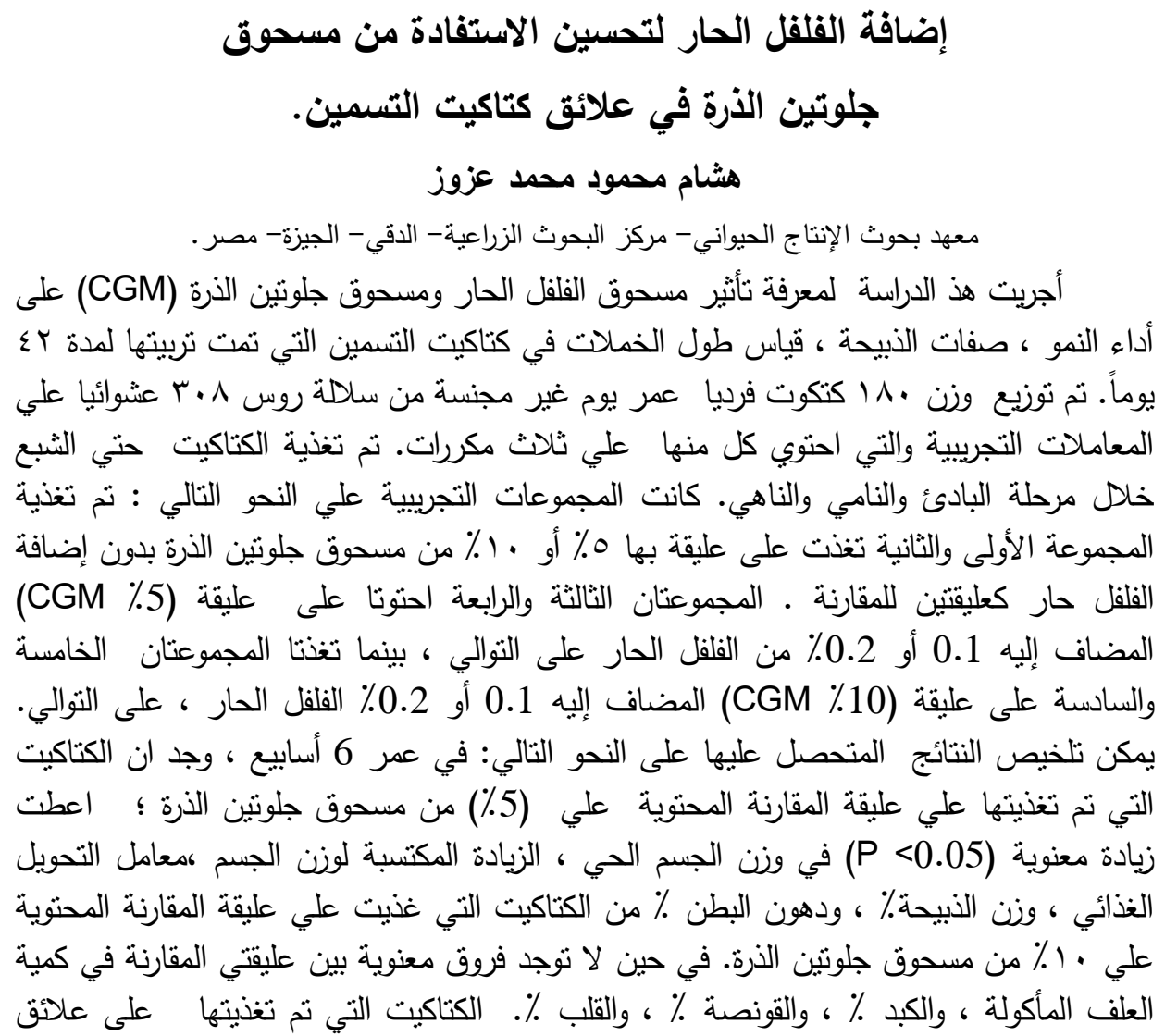




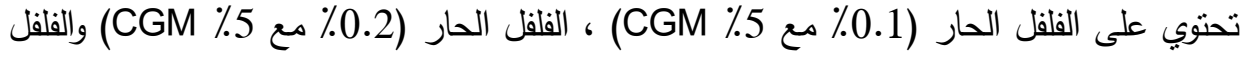

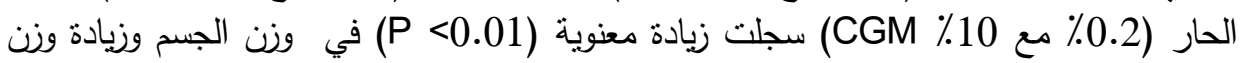

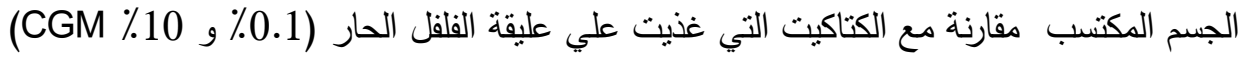

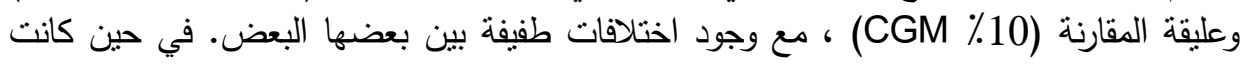

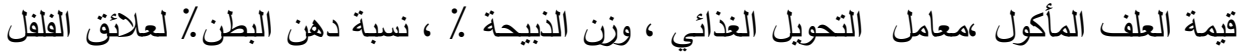

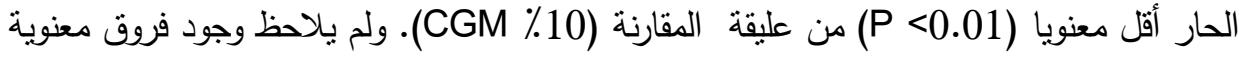

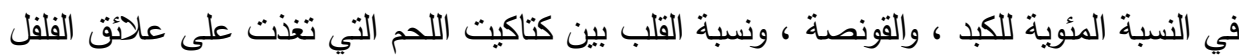
الحار و علائق المقارنة. كانت هنالك زيادات معنوية في طول الخملات مرنبطة بانخفاض فئنة

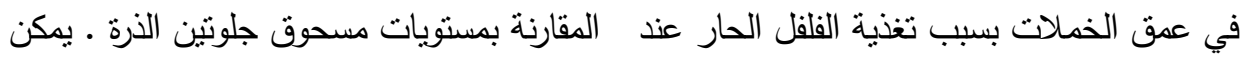

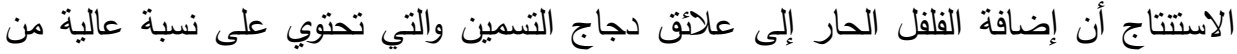

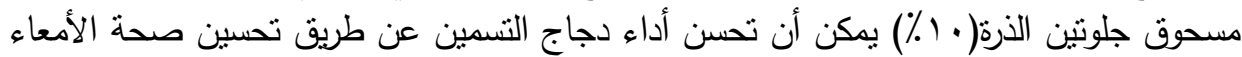
، الناتج عن زيادة طول الخملات ، وزيادة مسطح الامتصاص للأكعاء الدقيقة. 